\title{
Aktivitas Pemijahan, Perkembangan Awal, dan Pertumbuhan Larva Ikan Pelangi Arfak dalam Kondisi Laboratorium: Studi Pendahuluan untuk Penangkarannya
}

\author{
Spawning Activities, Early Development, and Larvae Growth of the Arfak \\ Rainbowfish in Laboratory Condition: A Preliminary Study for Its Breeding \\ Captivity
}

\author{
Emmanuel Manangkalangi ${ }^{1,5 *}$, Ida Lapadi ${ }^{1}$, Paskalina Theresia Lefaan ${ }^{2}$, M. Fadjar \\ Rahardjo $^{3,5}$, Renny K. Hadiaty ${ }^{4,5}$, Sigid Hariyadi ${ }^{3}$, Charles P. H. Simanjuntak ${ }^{3,5}$ \\ ${ }^{1}$ Jurusan Perikanan, Fakultas Perikanan dan Ilmu Kelautan, Universitas Papua, Manokwari, 98314, \\ Papua Barat, Indonesia \\ ${ }^{2}$ Jurusan Biologi, Fakultas Matematika dan Ilmu Pengetahuan Alam, Universitas Papua, \\ Manokwari, 98314, Papua Barat, Indonesia \\ ${ }^{3}$ Departemen Manajemen Sumberdaya Perairan, Fakultas Perikanan dan Ilmu Kelautan, Institut \\ Pertanian Bogor, 16680, Jawa Barat, Indonesia \\ ${ }^{4}$ (In Memoriam) Museum Zoologicum Bogoriense, Bidang Zoologi, Pusat Penelitian Biologi, \\ Lembaga Ilmu Pengetahuan Indonesia, Cibinong, 16911, Indonesia \\ ${ }^{5}$ Masyarakat Iktiologi Indonesia (MII) \\ *Korespondensi: e_manangkalangi2013@yahoo.com
}

\begin{abstract}
ABSTRAK
Informasi yang lengkap mengenai reproduksi, perkembangan awal, dan pertumbuhan larva menjadi sangat penting dalam upaya penangkaran dan reintroduksi spesies ikan yang terancam punah. Salah satu di antara spesies yang mulai terancam adalah ikan 331elangi Arfak, Melanotaenia arfakensis yang sudah berada dalam kategori rentan dan informasinya masih sangat terbatas. Oleh karena itu, penelitian ini dilakukan dengan tujuan untuk mendeskripsikan aktivitas pemijahan, perkembangan awal, dan pertumbuhan larva spesies ikan 331elangi ini dalam kondisi laboratorium. Percobaan dalam skala laboratorium dilaksanakan pada bulan Maret-September 2017. Ikan yang digunakan berasal dari Sungai Nimbai. Sebanyak tiga pasang individu jantan dan betina dengan kisaran ukuran 46,5 sampai 60,1 mm dipilih untuk perlakuan. Namun, hanya satu pasangan yang berhasil diamati aktivitas pemijahannya secara lengkap. Pemijahan berlangsung di antara waktu pagi hari sampai siang hari dalam tiga periode pemijahan. Dalam setiap periode, pemijahan berlangsung di antara 8 dan 11 hari. Antarperiode pemijahan membutuhkan waktu 14 sampai 22 hari. Setelah dibuahi, telur dilekatkan dengan filamen pada substrat pemijahan dan diletakkan pada kedalaman 7,3-24,3 cm dari permukaan air. Satu kelompok telur yang dipijahkan terdiri atas 78-116 butir dengan kisaran diameter di antara 1,05 dan $136 \mathrm{~mm}$. Telur menetas dalam periode 4 sampai 10 hari. Panjang tubuh larva yang baru menetas berkisar 4,13-4,40 mm dan akan mencapai ukuran $7,85 \mathrm{~mm}$ dengan tingkat sintasan $48,1 \%$ setelah 41 hari. Hasil penelitian ini menemukan beberapa kuntungan dari karakteristik pemijahan dan pertumbuhan tahap awal yang bermanfaat untuk upaya penangkaran dan pelepasliaran ikan ini ke habitat aslinya. Dengan demikian, populasinya di sistem Sungai Prafi dapat tetap dilestarikan.
\end{abstract}

Kata kunci: Ikan endemik; Melanotaenia; Penangkaran 


\begin{abstract}
Comprehensive information regarding the reproduction, early development, and growth of larvae is very important in the efforts of captive breeding and reintroduction of endangered fish species. One of the species that is starting to be threatened is the Arfak rainbowfish, Melanotaenia arfakensis which is already in the vulnerable category and its information is still relatively limited. Therefore, this study was conducted to describe the spawning activity, early development, and growth of the larvae of this rainbow fish species under laboratory conditions. Experiments on a laboratory scale were carried out in March-September 2017. The fish used came from the Nimbai Stream. A total of three pairs of individual males and females ranging in size from 46.5 to $60.1 \mathrm{~mm}$ were selected for treatment. However, only one pair was successfully observed spawning activity completely. Spawning takes place between morning and noon in three spawning periods. In each period, spawning lasts between 8 and 11 days. Between spawning periods takes 14 to 22 days. After fertilization, the eggs are attached with filaments to the spawning substrate and placed at a depth of 7.3-24.3 $\mathrm{cm}$ from the surface of the water. One group of eggs spawned consists of 78-116 eggs with a diameter range between 1.05 and $136 \mathrm{~mm}$. The eggs hatch in a period of 4 to 10 days. The body length of the newly hatched larvae ranges from $4.13-4.40 \mathrm{~mm}$ and will reach a size of $7.85 \mathrm{~mm}$ with a survival rate of $48.1 \%$ after 41 days. The results of this study found several advantages from the characteristics of spawning and growth in the early stages that are useful for captive breeding efforts and reintroduction of this rainbowfish to their natural habitat. Thus, its population in the Prafi River system can be maintained.
\end{abstract}

Keywords: Captive breeding; Endemic fish, Melanotaenia

\section{PENDAHULUAN}

Informasi tentang reproduksi memungkinkan untuk memahami hubungan di antara potensi reproduksi dan variasi lingkungan, misalnya terkait makanan, suhu energi, dan kondisi hidrologi (Lobon-Cervia et al. 1997, Kjesbu et al. 1998, Olden \& Kennard 2010). Oleh karena itu setiap spesies ikan memiliki strategi yang berbedabeda terhadap variabilitas kondisi lingkungan untuk mengoptimalkan rekrutmen (Balon 1984, Wootton 1984). Keberhasilan rekrutmen juga ditentukan selama periode awal siklus hidupnya (Rice et al. 1987) karena sebagian besar mortalitas ikan sangat tinggi selama tahap ini (Houde 1994).

Mortalitas yang terjadi terkait dengan kesesuaian atau ketidaksesuaian antara kondisi lingkungan dan persyaratan selama fase embrionik dan awal larva (Hutchings 1997, Houde 2002). Tingkat mortalitas yang tinggi pada tahap awal juga terkait dengan faktor kelaparan dan tekanan pemangsaan (Miller et al. 1988, Houde
1994). Kedua faktor ini sangat bergantung pada ukuran (Miller et al. 1988) dan oleh karena itu terkait dengan tingkat pertumbuhan. Ketika pertumbuhan berlangsung cepat, maka tingkat sintasan pada tahap-tahap awal siklus hidup ikan akan meningkat. Terkait dengan pertumbuhan larva, maka informasi mengenai cara memperoleh makanan dan proses pencernaannya akan sangat penting (Yúfera \& Darias 2007, Rønnestad \& Morais 2008, Portella \& Dabrowski 2008, Zambonino-Infante et al. 2008). Oleh karena itu, pemahaman mengenai aktivitas pemijahan, perkembangan tahap awal, dan pertumbuhan larva sangat penting untuk keberhasilan rekrutmen dan kestabilan struktur populasi di habitat alami (in-situ) maupun dalam upaya penangkaran (ex-situ).

Dalam kasus ikan pelangi arfak (Melanotaenia arfakensis) yang memiliki persebaran terbatas di perairan tawar Papua (Allen 1990) dan sudah termasuk dalam kategori rentan (vulnerable) (IUCN 2018), informasi 
mengenai aktivitas pemijahan, perkembangan tahap awal, dan pertumbuhan larva belum tersedia. Selain itu, berbagai dampak aktivitas antropogenik yang menyebabkan degradasi kualitas habitat ikan ini di Sungai Nimbai dan S. Aimasi telah dilaporkan (Manangkalangi et al. 2014, 2017, 2019, 2020, Leatemia et al. 2017, Lefaan et al. 2019) dan diduga menyebabkan penurunan populasinya. Berkaitan dengan kondisi yang ada, penelitian ini bertujuan untuk mendeskripsikan aktivitas pemijahan, perkembangan tahap awal, dan pertumbuhan larva ikan pelangi arfak sebagai informasi awal upaya perkembangbiakan dalam penangkaran.

\section{METODE PENELITIAN}

\section{Lokasi dan waktu penelitian}

Ikan pelangi arfak dewasa dikoleksi dari habitat alaminya di S. Nimbai pada bulan Maret dan April 2017. Penangkapan ikan ini dilakukan menggunakan alat tangkap hand net berukuran panjang $3 \mathrm{~m}$, tinggi $1,5 \mathrm{~m}$, dan mata jaring $1 \mathrm{~mm}$. Ikan ini selanjutnya dibawa ke Laboratorium Perikanan Fakultas Perikanan dan Ilmu Kelautan Universitas Papua dan dipelihara dalam akuarium berukuran 80 $\mathrm{cm} \times 35 \mathrm{~cm}$ x $40 \mathrm{~cm}$ (112 L). Kondisi kualitas air dalam akuarium disesuaikan dengan kondisi pada habitat aslinya dan selanjutnya diaklimatisasi pada kondisi laboratorium selama tiga bulan (Tabel 1) dan diberi pakan larva nyamuk dari tahap instar dan pupa.

Ikan pelangi arfak yang digunakan dalam percobaan aktivitas pemijahan dipilih berdasarkan ukuran panjang tubuh (panjang baku, PB) dan karakter morfologi kelamin sekunder untuk menentukan jenis kelamin dan ukuran yang telah matang kelamin (Manangkalangi et al. 2009b). Individu jantan dan betina yang digunakan berukuran di antara 46,5 dan $60,1 \mathrm{~mm}$ dan sebanyak tiga individu untuk setiap jenis kelamin. Namun, dalam pelaksanaan penelitian, aktivitas pemijahan hanya bisa diikuti pada satu pasangan saja.

Ikan pelangi yang telah dipisahkan berdasarkan ukuran yang telah matang kelamin ditempatkan dalam tiga akuarium berukuran sama (43 cm x $35 \mathrm{~cm} \times 40 \mathrm{~cm})$ dengan perbandingan jantan dan betina sesuai dengan yang ditemukan di habitat alami, yaitu 1:1 (Manangkalangi et al. 2009b). Oleh karena spesies ikan ini termasuk dalam kelompok fitofil (menempelkan telur pada bagian tumbuhan yang terendam) (Manangkalangi et al. 2009a,b), maka dalam percobaan ini digunakan kakaban yang terbuat dari ijuk sebagai substrat buatan untuk menempelkan telurnya. Penempatan substrat ini dilakukan secara tegak lurus untuk memudahkan pengukuran kedalaman peletakan setiap telur yang telah difertilisasi (kedalaman air dalam akuarium $\sim 35 \mathrm{~cm}$ ).

Tabel 1 Karakteristik kualitas air di habitat alami dan di laboratorium

\begin{tabular}{lcccl}
\hline \multirow{2}{*}{ Lokasi } & \multicolumn{3}{c}{ Parameter fisik dan kimia air } & \multirow{2}{*}{ Sumber } \\
\cline { 2 - 4 } & Suhu $\left({ }^{\circ} \mathrm{C}\right)$ & $\begin{array}{c}\text { Oksigen terlarut } \\
\left(\mathrm{mg}^{-1}\right)\end{array}$ & $\mathrm{pH}$ & \\
\hline Sungai Nimbai dan S. Aimasi & $24,6-28,6$ & $5,2-7,5$ & $7,9-8,6$ & $\begin{array}{l}\text { Manangkalangi } \\
\text { et al. (2009a) }\end{array}$ \\
& $24,0-27,5$ & $5,06-6,87$ & $6,63-7,98$ & $\begin{array}{l}\text { Manangkalangi et al. } \\
(2014)\end{array}$ \\
S. Nimbai & & & & \\
$\begin{array}{l}\text { Dalam Laboratorium } \\
\text { - tahap aklimatisasi }\end{array}$ & $26,3-27,9$ & $6,0-7,2$ & $7,22-7,87$ & \\
- pemijahan & $26,2-27,6$ & $6,0-7,3$ & $7,46-7,92$ & Penelitian ini \\
- penetasan, pertumbuhan, dan \\
tingkat sintasan & $26,8-27,7$ & $6,6-7,5$ & $7,25-7,93$ & \\
\hline
\end{tabular}


Aktivitas pemijahan diamati setiap hari. Setelah proses pemijahan selesai, maka kakaban yang terdapat telur dipindahkan ke dalam akurium lainnya untuk melindungi telur dan memudahkan pengamatan terhadap telur yang dihasilkan. Akuarium penetasan telur dan pemeliharaan larva berukuran $30 \mathrm{~cm} \times 18 \mathrm{~cm}$ x $23 \mathrm{~cm}$ dengan kapasitas $10 \mathrm{~L}$ yang dilengkapi dengan pemanas otomatis (Resun $\AA$ ) yang diatur pada suhu $27^{\circ} \mathrm{C}$. Jumlah telur yang dihasilkan dalam setiap pemijahan dihitung untuk mendapatkan fekunditasnya. Selanjutnya telur-telur dilepaskan dari kakaban dengan bantuan gunting dan pinset. Telur selanjutnya ditempatkan pada kaca obyek dan diamati secara langsung di mikroskop optik (Olympus $\left.{ }^{\circledR} \quad \mathrm{Cx} 31\right)$ yang dilengkapi dengan kamera (Colour CCTV Camera Panasonic ${ }^{\circledR}$ WVCP480/G) dengan pembesaran 40x dan mikrometer untuk pengukuran diameter telur. Setelah diamati, telur dikembalikan ke akuarium penetasan.

Larva hasil penetasan dihitung jumlahnya dan dipelihara pada akuarium penetasan. Selama masa pemeliharaan, setelah larva yang berumur 3 hari diberi penambahan pakan berupa larva nyamuk dari tahap instar I dan pellet komersial yang telah dihaluskan. Tahap perkembangan pralarva-pascalarva diamati karakteristiknya berdasarkan Humphrey et al. (2003), serta dihitung jumlah individunya secara harian untuk mendapatkan tingkat sintasan (survival rate) dan diukur panjang tubuhnya untuk pertumbuhan. Tingkat sintasan dan pertumbuhan tahap larva diikuti selama 41 hari. Untuk analisis pertumbuhan, sebanyak 12 individu larva dipilih dan diukur panjang bakunya dalam periode pengamatan ini.

Selama pengamatan aktivitas pemijahan, penetasan dan pemeliharaan larva, diukur suhu air dan oksigen terlarut dengan DO meter yang dilengkapi termometer, serta tingkat keasaman air dengan $\mathrm{pH}$ meter. Pengukuran dilakukan sebanyak dua kali setiap hari, yaitu 08.00-09.00 dan 17.0018.00. Kondisi pencahayaan dalam laboratorium diatur dengan periode 12 jam terang dan 12 jam gelap.

\section{Analisis data}

Untuk memetakan pertumbuhan larva ikan digunakan regresi linier, yaitu: $\mathrm{Y}=\mathrm{a}+\mathrm{bX}$. Notasi $\mathrm{Y}$ adalah ukuran panjang tubuh larva ke-i, $X$ adalah umur larva (hari setelah menetas), a dan b adalah koefisien regresi. Analisis ini dikerjakan menggunakan program MS-Excel 2010.

\section{HASIL DAN PEMBAHASAN}

\section{Aktivitas dan tipe pemijahan}

Sebelum aktivitas pemijahan berlangsung, individu jantan menunjukkan tingkah laku yang aktif mengejar individu betina, dan menempelkan ujung mulutnya di sekitar bagian perut individu betina. Aktivitas pemijahan berlangsung di sekitar substrat pemijahan, ketika individu betina dan jantan berenang dalam posisi yang relatif beriringan, serta mengeluarkan telur dan sperma secara bersamaan. Aktivitas ini berlangsung pada waktu pagi-siang hari (Tabel 2). Telur yang dipijahkan melekat (adhesive) dengan filamen pada substrat pemijahan dalam kolom air yang relatif dekat dengan permukaan, yaitu pada kedalaman antara 7,3 dan $24,3 \mathrm{~cm}$ dari permukaan air. Proporsi terbesar telur diletakan pada kedalaman di antara 10,1 dan 15,0 cm dari permukaan air (Gambar 1). Setelah proses pemijahan, aktivitas pergerakan kedua individu menjadi berkurang, dan individu jantan cenderung berada di sekitar substrat pemijahan.

Pemilihan waktu pemijahan ini (pagi-siang hari) diduga berkaitan dengan karakteristik ikan ini yang aktif pada waktu siang hari (diurnal) serta untuk memudahkan pemilihan lokasi pemijahan dan substrat penempelan telur yang sesuai untuk keberhasilan aktivitas pemijahan dan memaksimalkan sintasan yang akan dihasilkan. Berdasarkan 
penelitian sebelumnya (Manangkalangi 2009, Kadarusman et al. 2010), ikan pelangi arfak umumnya ditemukan pada perairan yang relatif jernih $(<58,1$ NTU). Keberhasilan pemijahan ikan ini diduga akan sangat dipengaruhi oleh kejernihan perairan dan keberadaan pemangsa. Pada perairan yang jernih dan mengalir, ikan sangat bergantung pada daya penglihatan untuk mengidentifikasi habitat yang berbahaya (terkait dengan kehadiran pemangsa) (Chivers \& Smith 1994, 1995). Mekanisme penghindaran terhadap habitat yang berasosiasi dengan pemangsa juga telah diamati pada ikan pelangi (Brown 2003).

Tabel 2. Waktu pemijahan ikan pelangi arfak dalam kondisi laboratorium

\begin{tabular}{ccc}
\hline $\begin{array}{c}\text { Periode } \\
\text { Pemijahan }\end{array}$ & Tanggal & Jam \\
\hline I & 18 Juni 2017 & 10:13 WIT \\
I & 22 Juni 2017 & 08:03 WIT \\
II & 10 Juli 2017 & 12:30 WIT \\
II & 11 Juli 2017 & 09:02 WIT \\
II & 13 Juli 2017 & 06:03 WIT \\
III & 8 Agustus & 11:23 WIT \\
& 2017 \\
III & 12 Agustus & 10:49 WIT \\
& 2017 \\
III & 15 Agustus & 09:35 WIT \\
& 2017 \\
\hline
\end{tabular}

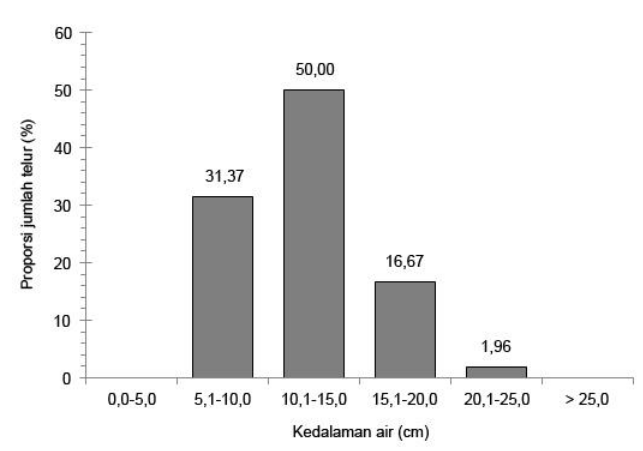

Gambar 1. Proporsi jumlah telur berdasarkan kedalaman peletakannya pada substrat pemijahan

Salah satu pemangsa utama ikan pelangi, yaitu Glossamia aprion, banyak ditemukan pada area kolom air dengan rerumputan yang padat (Hattori \& Warburton 2003) yang merupakan habitat pemijahan dan pembesaran larva ikan pelangi. Selain kehadiran pemangsa, keberhasilan aktivitas pemijahan juga dipengaruhi oleh persaingan areal pemijahan. Hasil penelitian Doupe et al. (2009) menunjukkan bahwa kehadiran Oreochromis mossambicus dapat mengganggu keberhasilan pemijahan ikan pelangi $M$. splendida sehingga menyebabkan penurunan produksi telur dan proporsi telur yang dibuahi masingmasing lebih dari $70 \%$ dan $30 \%$. Mekanisme gangguan dari ikan asing ini terkait dengan aktivitas reproduksinya yang mengganggu melalui tingkat produksi hormon dan feromon yang tinggi, kompetisi habitat pemijahan dan/atau agresifitas individu jantan yang menjaga areal pemijahan dan anakan (Oliveira et al. 1996; Oliveira \& Almada 1998; Morgan et al. 2004; Maddern et al. 2007).

Beberapa penelitian lainnya juga menunjukan arti penting habitat pemijahan yang sesuai untuk meminimalkan jenis dan intensitas gangguan terhadap telur yang dihasilkannya. Gangguan yang nyata terhadap perkembangan tahap awal ini di antaranya, yaitu predasi, hipoksia, penutupan lumpur (Wootton 1990) dan kekeringan karena terpapar udara yang cukup lama (Oulton et al. 2013b) yang terkait dengan pemilihan kedalaman penempelan telur. Sebagai contoh, dalam pengamatan skala laboratorium menunjukan bahwa kehadiran pemangsa alami akan memperlambat penetasan telur pada embrio M. duboulayi (Oulton et al. 2013a). Dalam percobaan skala laboratorium, Oulton et al. (2013b) menunjukkan bahwa hampir $100 \%$ mortalitas telur ikan pelangi terjadi ketika 15 menit terpapar udara dan pemilihan tipe substrat penempelan telur juga berimplikasi terhadap tingkat sintasan sebesar $20 \%$ sampai telur menetas setelah satu jam terpapar udara. Selain itu, pemilihan kedalaman ini juga untuk menjamin tingkat oksigen yang 
cukup bagi telur yang dihasilkan, walaupun hasil penelitian Flint et al. (2018) dalam skala laboratorium menunjukkan bahwa embrio $M$. utcheensis mampu menolerasi kondisi hipoksia (kejenuhan minimal 5\%). Pemilihan kedalaman penempelan juga diduga untuk menghindari pengaruh penutupan sedimen halus terhadap telur. Dampak fisik sedimen halus terjadi karena pengurangan pasokan oksigen ke telur (Greig et al. 2005a, 2007) melalui mekanisme penutupan secara fisik mikropori pada permukaan telur (Greig et al. 2005b).

Pada habitat alami, konsentrasi waktu pemijahan dan posisi peletakan telur diduga juga merupakan salah satu bentuk adaptasi terhadap fluktuasi permukaan air sungai sehingga terhindar dari kondisi terpapar udara dan terhindar dari penutupan sedimen halus. Hasil penelitian sebelumnya (Manangkalangi et al. 2009b) menunjukkan bahwa periode puncak pemijahan ikan pelangi arfak pada habitat alaminya berlangsung pada musim kemarau dengan kondisi permukaan air yang relatif stabil. Selama periode ini, khususnya pada habitat di bagian tepi sungai dengan aliran air yang relatif tenang, ditemukan kelimpahan makanan yang lebih tinggi dan suhu air yang lebih hangat sehingga memungkinkan metabolisme dan pertumbuhan larva menjadi lebih cepat (Humphries et al. 1999, Manangkalangi et al. 2009c).
Pemijahan ikan pelangi arfak berlangsung setiap hari selama $8-11$ hari dalam satu periode. Proses pemijahan pada jenis ikan ini bisa berlangsung lebih dari satu periode. Selang waktu antarperiode pemijahan berlangsung 1422 hari (Gambar 2). Pemijahan yang berlangsung lebih dari satu periode menunjukkan bahwa ikan ini termasuk dalam kelompok tipe pemijah bertahap (batch spawner atau multiple spawner). Beberapa bukti terkait dengan tipe pemijahan di habitat alami yang berlangsung secara bertahap pada famili Melanotaeniidae juga telah ditunjukkan oleh penelitian sebelumnya, misalnya berkaitan dengan proporsi telur yang akan dipijahkan (Pusey et al. 2001) (Tabel 3), dan perbedaan ukuran diameter telur dalam ovarium yang menunjukan tahap perkembangannya (Manangkalangi et al. 2009b). Walaupun demikian, ada kemungkinan bahwa ikan pelangi melakukan pemijahan dalam periode waktu yang lebih panjang (lebih dari tiga periode). Bukti terkait dengan pemanjangan periode pemijahan telah dinyatakan oleh Hismayasari et al. (2015) yang membuktikan secara histologis keberadaan delapan tahap perkembangan oosit pada M. boesemani dan Pusey et al. (2002) melalui kehadiran larva sepanjang tahun di Sungai Johnstone.

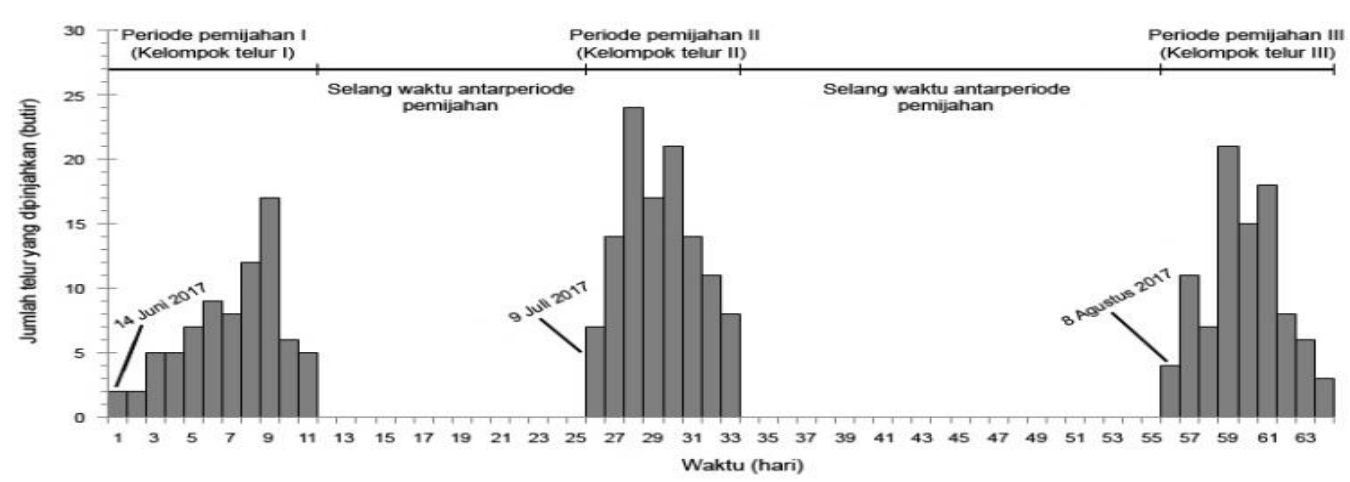

Gambar 2. Periode pemijahan dan selang waktu antarperiode pada satu pasangan individu dewasa ikan pelangi arfak 
Kondisi ini merupakan salah satu bentuk strategi terhadap variabilitas pada kondisi alami, di antaranya berkaitan dengan hidrologi, suhu, dan kelimpahan makanan, untuk mengoptimalkan rekrutman. Strategi ini termasuk kelompok 'opportunistik' (Winemiller \& Rose 1992) dan ikan pelangi (Melanotaeniidae) termasuk salah satu contoh kelompok strategi ini (Olden \& Kennard 2010).

\section{Jumlah dan diameter telur dalam periode pemijahan}

Hasil penelitian ini menunjukkan bahwa jumlah telur dalam satu periode pemijahan berkisar 78-116 butir. Telur yang dihasilkan dalam tiga periode pemijahan ini adalah fekunditas total, karena tidak terjadi pemijahan dalam satu bulan waktu pengamatan berikutnya. Diameter telur yang dipijahkan dalam tiga periode pemijahan di antara 1,05 dan 1,36 mm.

Kami memperkirakan bahwa jumlah telur yang dihasilkan dalam penelitian ini (selama tiga periode) adalah fekunditas total. Selain berdasarkan pengamatan, dugaan ini juga diperkuat dengan menggunakan hubungan persamaan antara panjang baku (PB) dan fekunditas ikan pelangi arfak yang berasal dari habitat alami di Sungai Nimbai (Manangkalangi 2009), yaitu dugaan fekunditas dari individu betina berukuran PB $46,5 \mathrm{~mm}$ adalah 308 butir telur. Berdasarkan dugaan ini, maka kelompok telur yang dihasilkan dalam setiap periode pemijahan berkisar antara 27,2 dan $40,4 \%$ dari fekunditas total.

Tabel 3 Fekunditas dan diameter telur pada beberapa jenis ikan pelangi

\begin{tabular}{|c|c|c|c|c|c|c|}
\hline \multirow[b]{2}{*}{ Spesies } & \multicolumn{3}{|c|}{ Fekunditas } & \multicolumn{2}{|c|}{ Diameter telur (mm) } & \multirow[b]{2}{*}{ Sumber } \\
\hline & $\begin{array}{l}\text { Total } \\
\text { (butir) }\end{array}$ & $\begin{array}{c}\text { Setiap } \\
\text { periode } \\
\text { pemijahan } \\
(\%)\end{array}$ & $\begin{array}{l}\text { Panjang Tubuh } \\
\text { Individu Betina } \\
\qquad(\mathrm{mm})\end{array}$ & Kisaran & Rata-rata & \\
\hline $\begin{array}{l}\text { Melanotaenia } \\
\text { arfakensis }\end{array}$ & $287^{c}$ & $27,2-40,4^{\mathrm{e}}$ & $46,5^{\mathrm{g}}$ & $1,05-1,36^{\mathrm{i}}$ & 1,10 & Penelitian ini \\
\hline M. arfakensis $^{\mathrm{a}}$ & $23-967^{d}$ & - & $27,41-64,94^{\mathrm{g}}$ & $0,5^{\mathrm{j}}-1,2^{\mathrm{k}}$ & 0,81 & \multirow{2}{*}{$\begin{array}{l}\text { Manangkalangi et } \\
\text { al. }(2009 \mathrm{~b})\end{array}$} \\
\hline M. arfakensis ${ }^{\mathrm{b}}$ & $64-1.351^{\mathrm{d}}$ & - & $28,76-70,27^{g}$ & $0,5^{\mathrm{j}}-1,3^{\mathrm{k}}$ & 0,82 & \\
\hline M. duboulayi & - & - & - & $0,88-0,93^{\mathrm{i}}$ & 0,91 & $\begin{array}{l}\text { Crowley et al. } \\
\text { (1986) }\end{array}$ \\
\hline M. eachamensis & $\begin{array}{l}206- \\
2.126^{\mathrm{d}}\end{array}$ & $2,2-16,4^{f}$ & $49-62^{g}$ & $\begin{array}{l}1,207- \\
1,324^{\mathrm{k}}\end{array}$ & 1,238 & Pusey et al. (2001) \\
\hline \multirow{3}{*}{ M. fluviatilis } & - & - & - & $0,98-1,07^{\mathrm{i}}$ & 1,02 & $\begin{array}{l}\text { Reid \& Holdway } \\
\text { (1995) }\end{array}$ \\
\hline & - & - & - & $0,93-0,95^{\mathrm{i}}$ & 0,94 & $\begin{array}{l}\text { Crowley et al. } \\
(1986)\end{array}$ \\
\hline & $35-333^{d}$ & - & $30,8-58,4^{g}$ & - & $1,41^{\mathrm{k}}$ & $\begin{array}{l}\text { Milton \& } \\
\text { Arthington (1984) }\end{array}$ \\
\hline M. nigrans & - & - & - & $1,00-1,08^{\mathrm{i}}$ & 1,05 & $\begin{array}{l}\text { Crowley \& } \\
\text { Ivantsoff (1982) }\end{array}$ \\
\hline M. praecox & - & - & - & $0,99-1,04^{\mathrm{i}}$ & 1,02 & Radael et al. (2013) \\
\hline \multirow{3}{*}{ M. splendida } & - & - & - & $0,93-1,20^{\mathrm{i}}$ & 1,04 & $\begin{array}{l}\text { Humphrey et al. } \\
\text { (2003) }\end{array}$ \\
\hline & $\begin{array}{l}370- \\
1.655^{\mathrm{d}}\end{array}$ & $0,9-13,8^{f}$ & $40-70^{\mathrm{g}}$ & - & $1,124^{\mathrm{k}}$ & Pusey et al. (2001) \\
\hline & - & - & - & $0,87-0,92^{\mathrm{i}}$ & 0,88 & $\begin{array}{l}\text { Crowley \& } \\
\text { Ivantsoff (1982) }\end{array}$ \\
\hline $\begin{array}{l}\text { Glossolepis } \\
\text { incisus }\end{array}$ & $\begin{array}{l}910- \\
3.122^{\mathrm{d}}\end{array}$ & $12,4-25,1^{\mathrm{f}}$ & $95-120^{\mathrm{h}}$ & - & - & Siby et al. (2009) \\
\hline $\begin{array}{l}\text { Cairnsichthys } \\
\text { rhombosomoides }\end{array}$ & $131-737^{\mathrm{d}}$ & $2,5-13,4^{\mathrm{f}}$ & $35,5-57^{g}$ & - & $1,091^{\mathrm{k}}$ & Pusey et al. (2001) \\
\hline
\end{tabular}

Keterangan: ${ }^{a}$ Sungai Nimbai, ${ }^{b}$ Sungai Aimasi, jumlah telur yang dipijahkan, dugaan jumlah telur dalam ovarium, epengamatan dalam laboratorium, ${ }^{\mathrm{f}}$ pengamatan di habitat alami, ${ }^{\mathrm{g}}$ panjang baku (ujung anterior mulut sampai ujung tulang hypural di bagian dasar sirip ekor), hpanjang total (ujung anterior mulut sampai ujung posterior sirip ekor), ${ }^{\mathrm{i}}$ diameter telur setelah fertilisasi, ${ }^{\mathrm{j}}$ diameter telur di bagian anterior ovarium, ${ }^{\mathrm{k}}$ diameter telur yang siap dipijahkan di bagian posterior ovarium. 
Kondisi ini menunjukkan bahwa proporsi telur yang dipijahkan kemungkinan relatif lebih besar dibandingkan pengamatan pada habitat alaminya (Tabel 3). Hal ini diduga terkait dengan kondisi lingkungan dalam laboratorium yang relatif lebih stabil, sehingga upaya pemijahan dilakukan lebih maksimal dalam periode yang lebih singkat.

Seperti halnya ikan pelangi yang lain, ukuran telur ikan pelangi arfak yang dipijahkan relatif berukuran besar (Tabel 3). Hal ini merupakan karakteristik famili Melanotaeniidae, dan sebagai respons adaptif untuk memaksimalkan keberhasilan reproduksi pada lingkungan yang bervariasi dan tidak dapat diprediksi (Einum \& Fleming 2004). Telur yang berukuran besar akan menghasilkan tingkat sintasan yang lebih tinggi dan laju pertumbuhan yang lebih cepat, seperti yang dilaporkan oleh Singh et al. (2006).

\section{Periode telur menetas}

Periode waktu menetas telur setelah fertilisasi berkisar di antara empat dan 10 hari. Namun, proporsi terbesar terutama berlangsung pada hari ke tujuh, yaitu sebesar 27,9 \% (Gambar 3 ). Periode telur menetas yang relatif singkat diduga merupakan salah satu karakteristik kelompok ikan pelangi (Melanotaeniidae) yang termasuk dalam kelompok daur hidup oportunistis (Tabel 3). Namun, waktu penetasan ini sangat terkait dengan suhu perairan. Hasil penelitian Radael et al. (2015) dalam skala laboratorium menunjukkan bahwa perkembangan embrio Melanotaenia boesemani berlangsung dalam periode yang lebih singkat pada kondisi suhu air yang lebih hangat.

Kondisi suhu air yang lebih hangat merupakan karakteristik perairan pada musim kemarau. Oleh karena itu, konsentrasi pemijahan pada musim kemarau merupakan salah satu strategi untuk mempercepat perkembangan embrio pada ikan pelangi. Pola yang sama juga dilaporkan terjadi pada ikan endemik Coilia nasus di Teluk Ariake, Jepang yakni musim pemijahan terjadi pada musim panas yang memungkinkan perkembangan embrio berlangsung dengan cepat (Simanjuntak et al. 2015).

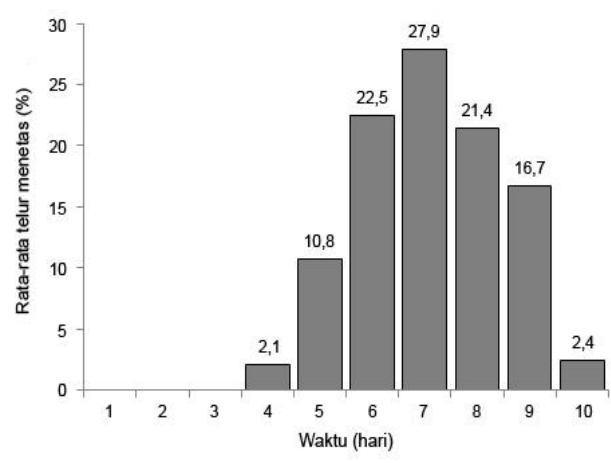

Gambar 3. Persentase jumlah telur ikan pelangi arfak yang menetas berdasarkan hari

Periode embriologi ikan pelangi arfak yang singkat ini diduga merupakan salah satu bentuk strategi untuk menghadapi kondisi hidrologi lingkungan sungai yang lebih ektrim pada musim hujan yang berfluktuasi secara harian dan untuk memaksimalkan pertumbuhan larvanya. Hasil penelitian sebelumnya (Manangkalangi et al. 2009b) menunjukkan bahwa periode pemijahan pada ikan pelangi arfak terutama berlangsung pada akhir musim kemarau dengan kondisi aliran yang lebih stabil, kelimpahan makroavertebrata yang lebih tinggi khususnya di bagian tepi sungai dan temperatur air yang lebih hangat. Kondisi ini akan meningkatkan metabolisme dan pertumbuhan tahap awal ikan pelangi (Humphries et al. 1999). 
Tabel 4. Periode telur menetas pada beberapa jenis ikan pelangi

\begin{tabular}{lcccl}
\hline \multirow{2}{*}{ Spesies } & \multicolumn{3}{c}{ Periode telur menetas (hari) } & \\
\cline { 2 - 4 } & Kisaran & Rata-rata & Suhu air $\left({ }^{\circ} \mathrm{C}\right)$ & \\
\hline Melanotaenia arfakensis & $4-10$ & 7 & $26,8-27,7$ & Penelitian ini \\
M. duboulayi & - & $4,4-4,5$ & $27 \pm 1$ & Crowley et al. $(1986)$ \\
& $7-9$ & - & $25 \pm 1$ & Reid \& Holdway (1995) \\
M. fluviatilis & - & $4,5-4,6$ & $27 \pm 1$ & Crowley et al. $(1986)$ \\
& $6-7$ & - & $26-27$ & Milton \& Arthington (1984) \\
M. nigrans & - & $6,46-6,63$ & $25 \pm 1$ & Crowley \& Ivantsoff $(1982)$ \\
M. praecox & - & 4,98 & $28,06 \pm 0,49$ & Radael et al. (2013) \\
M. splendida & $4-8$ & 5 & $28 \pm 1$ & Humphrey et al. $(2003)$ \\
& - & $6,29-6,33$ & $25 \pm 1$ & Crowley \& Ivantsoff $(1982)$ \\
\hline
\end{tabular}
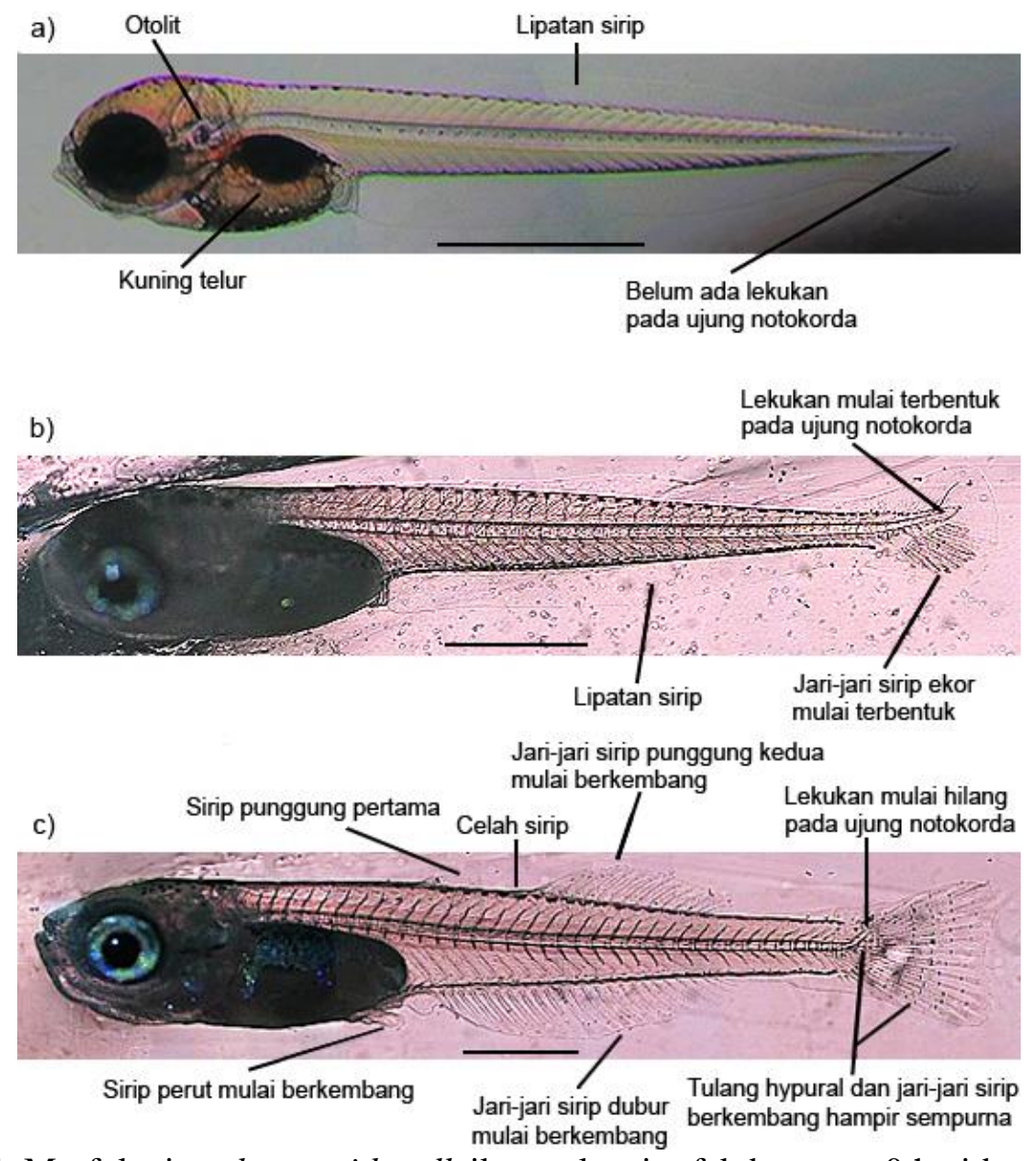

Gambar 4. Morfologi prelarva with yolk ikan pelangi arfak berumur 0 hari berukuran. a) PB 4,13 mm, b) flexion berumur 23 hari dengan PB 6,37 $\mathrm{mm}$, dan c) postflexion berumur 38 hari dengan $\mathrm{PB} 7,17 \mathrm{~mm}$. Skala batang $=1 \mathrm{~mm}$

\section{Ukuran larva yang baru menetas dan perkembangan morfologi larva}

Ukuran panjang tubuh larva ikan pelangi arfak yang baru menetas berkisar di antara 4,13 dan 4,40 $\mathrm{mm}$. Pada saat menetas, larva ikan pelangi arfak sudah memiliki sirip dada, walaupun belum berkembang secara sempurna.

Dalam penelitian ini berhasil didokumentasi tiga tahap perkembangan larva berdasarkan karakteristik morfologinya, yaitu preflexion with yolk, flexion, dan postflexion. Tahap preflexion with yolk dicirikan tidak ada lekukan pada ujung notokorda, sirip 
punggung dan anal masih berupa lipatan dan menyatu dengan sirip ekor (Gambar 4a), serta sirip dada yang sudah berkembang. Pada tahap flexion (umur 23 hari), lekukan pada ujung notokorda mulai terbentuk dan jari-jari sirip ekor di bagian ventral mulai terbentuk (Gambar $4 b$ ), sedangkan pada tahap postflexion (umur 38 hari), lekukan pada ujung notokorda mulai hilang dan tulang hypural dan jari-jari sirip ekor berkembang hampir sempurna (Gambar 4c). Pada tahap postflexion, juga ditandai dengan sirip perut yang mulai terbentuk dan jari-jari sirip punggung, anal, serta ekor mulai berkembang.

Larva ikan pelangi arfak yang baru menetas berukuran relatif lebih besar dibandingkan dengan jenis ikan pelangi lainnya (Tabel 4). Hal ini diduga berkaitan dengan ukuran diameter telurnya yang relatif lebih besar dibandingkan jenis ikan lainnya (Tabel 3). Ukuran larva yang besar memiliki pertumbuhan yang cepat dan tingkat sintasan yang lebih tinggi (Einum \& Fleming 1999, 2000). Hal ini diduga terkait dengan kemampuan renangnya. Miller et al. (1988) mengemukakan bahwa kecepatan berenang larva berkorelasi secara positif dengan ukuran tubuhnya. Oleh karena itu, larva yang berukuran lebih besar memiliki kemampuan untuk mendapatkan makanan (tingkat pertemuaan dengan makanan yang lebih besar) atau melepaskan diri dari pemangsa (Miller et al. 1988).

Secara morfologi, larva ikan pelangi arfak yang baru menetas sudah memiliki sirip dada dan membran sirip yang masih menyatu di antara bagian punggung, ekor dan anal (Gambar 4). Larva pada tahap ini sudah berenang secara aktif. Kondisi yang sama juga dilaporkan pada larva jenis ikan pelangi lainnya, misalnya Melanotaenia boesemani (Yuliani et al. 2013), M. fluviatilis (Reid \& Holdway 1995), dan M. splendida (Humphrey et al. 2003).

\section{Pertumbuhan dan sintasan larva pada skala laboratorium}

Hasil pengukuran panjang baku larva ikan pelangi arfak sampai umur 41 hari ditampilkan pada Gambar 5. Laju pertumbuhan lambat sampai larva berumur 8 hari dan selanjutnya mulai cepat sampai umur 23 hari, dan mulai menurun kembali.

Pada periode umur 0-8 hari laju pertumbuhan masih lambat. Hal ini diduga berkaitan dengan ukuran bukaan mulut dan sumber makanannya yang masih terbatas, yaitu berupa kuning telur. Kuning telur akan tereduksi dalam 3-5 hari setelah menetas, butir-butir minyak (oil droplets) akan diserap (Reid \& Holdway 1995).

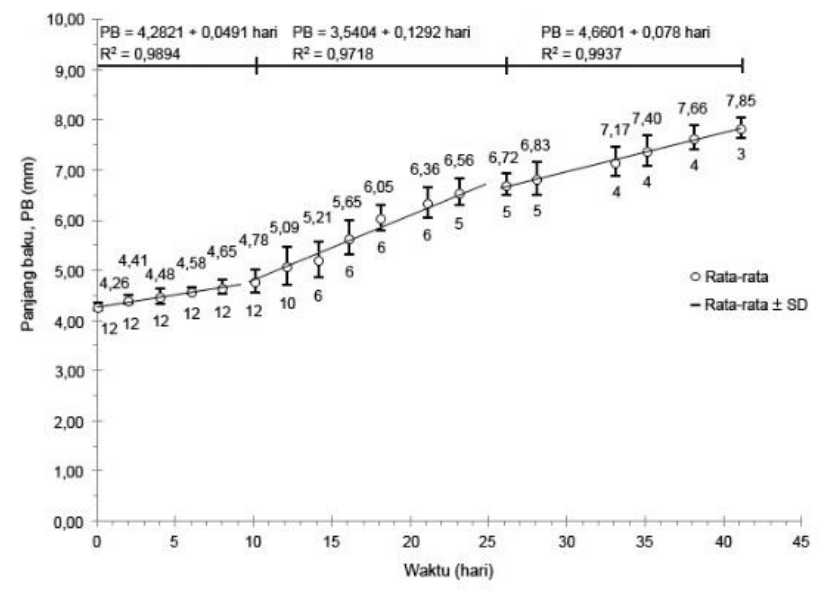

Gambar 5. Kurva pertumbuhan larva ikan pelangi arfak (angka di bagian atas adalah panjang baku rata-rata berdasarkan umur, dan angka di bagian bawah adalah jumlah individu yang diamati) 
Pada periode selanjutnya (umur 10-23 hari) dengan panjang baku ratarata di antara 4,78 dan $6,56 \mathrm{~mm}$, laju pertumbuhan semakin meningkat. Pertumbuhan yang meingkat ini diduga berkaitan dengan pemanfaatan sumber makanan yang berasal dari luar, yaitu instar I dan pellet. Pada periode ini, tahap larva berada dalam periode pertumbuhan, sehingga sebagian besar energi digunakan untuk pertumbuhan yang dicirikan dengan pertambahan ukuran panjang tubuh ikan.

Pada periode umur selanjutnya (lebih dari 23 hari), laju pertumbuhan panjang ikan mulai melambat. Pelambatan laju pertumbuhan panjang tubuh pada periode ini diduga berkaitan dengan perubahan dari tahap preflexion menjadi flexion dan postflexion, sehingga sebagian energi yang diperoleh dipergunakan untuk perkembangan sirip (yaitu, sirip punggung, anal dan ekor) (Gambar 5). Humphrey et al. (2003) mengemukakan bahwa jari-jari sirip dada, jari-jari sirip punggung kedua, dan jari-jari sirip anal mulai berkembang pada ukuran panjang tubuh $6,8-7,3 \mathrm{~mm}$ pada $M$. splendida.

Perbedaan laju pertumbuhan pada tahap awal perkembangan juga dilaporkan pada $M$. splendida yang menunjukkan laju pertumbuhan yang masih lambat sampai periode umur 12 hari dan mulai meningkat pada periode umur selanjutnya (Humphrey et al. 2003).

Pada periode ini, berlangsung proses pembentukan cartilaginous unsur-unsur hypural di bagian ekor, pembengkokan notokorda, pembentukan tulang epural, penebalan jaringan dan ukuran sirip punggung kedua dan sirip anal (Humphrey et al. 2003).

Walaupun ikan pelangi arfak memiliki ukuran diameter telur dan larva yang baru menetas relatif lebih besar dari jenis ikan pelangi lainnya, namun laju pertumbuhannya relatif lebih lambat dibandingkan beberapa jenis ikan pelangi yang lain (Tabel 5). Kondisi diduga terkait dengan tipe dan ukuran makanan yang digunakan dalam pemeliharaan larva yang belum tepat dalam penelitian ini. Pertumbuhan larva yang lambat dalam penelitian ini juga diduga berkaitan dengan pengaruh suhu air yang relatif lebih rendah sehingga laju metabolismenya juga lebih lambat (Tabel 5). Kesesuaian tipe makanan dan suhu air akan sangat berpengaruh terhadap pertumbuhan larva ikan yang digunakan dalam perlakuan ini yang relatif lebih rendah.

Hasil pengamatan menunjukkan bahwa rata-rata tingkat sintasan larva ikan pelangi arfak masih 93,7 $\%$ sampai hari ke-5 dan selanjutnya menurun secara drastis sampai $57,0 \%$ pada hari ke-14 (Gambar 6). Larva sampai umur 5 hari masih memanfaatkan cadangan makanan berupa kuning telur (endogenous); sedangkan penurunan tingkat sintasan pada larva berumur lebih dari 5 hari diduga berkaitan dengan ketersediaan kuning telur yang habis dan mulai beralih ke makanan yang berasal dari luar (exogenous) berupa larva nyamuk dari instar I dan pellet yang telah dihaluskan.

Tabel 5 Ukuran panjang tubuh larva dan umur pada beberapa jenis ikan pelangi

\begin{tabular}{|c|c|c|c|c|c|c|c|c|}
\hline \multirow{3}{*}{ Spesies } & \multicolumn{6}{|c|}{ Panjang tubuh larva (mm) } & \multirow{3}{*}{$\begin{array}{l}\text { Suhu air } \\
\left({ }^{\circ} \mathrm{C}\right)\end{array}$} & \multirow{3}{*}{ Sumber } \\
\hline & \multicolumn{2}{|c|}{0 hari (saat menetas) } & \multirow{2}{*}{$\begin{array}{c}14-16 \\
\text { hari }\end{array}$} & \multirow{2}{*}{$\begin{array}{c}20-22 \\
\text { hari }\end{array}$} & \multirow{2}{*}{$\begin{array}{c}\text { 30-33 } \\
\text { hari }\end{array}$} & \multirow{2}{*}{$\begin{array}{c}41 \\
\text { hari }\end{array}$} & & \\
\hline & Kisaran & Rata-rata & & & & & & \\
\hline M. arfakensis & $4,13-4,40$ & 4,26 & 5,65 & 6,36 & 7,17 & 7,85 & $26,8-27,7$ & Penelitian ini ${ }^{\mathrm{a}}$ \\
\hline M. boesemani & - & 4,71 & 8,12 & - & 13,80 & - & $27-28$ & Yuliani et al. $(2013)^{\mathrm{b}}$ \\
\hline M. duboulayi & $3,07-4,20$ & - & - & - & - & - & $27 \pm 1$ & Crowley et al. $(1986)^{\mathrm{b}}$ \\
\hline \multirow{2}{*}{ M. fluviatilis } & - & 4,20 & $\sim 5,50^{\mathrm{d}}$ & $\sim 8,00^{\mathrm{d}}$ & 13,86 & - & $25 \pm 1$ & Reid \& Holdway $(1995)^{\mathrm{a}}$ \\
\hline & $3,70-4,20$ & - & - & - & & - & $27 \pm 1$ & Crowley et al. $(1986)^{b}$ \\
\hline M. splendida & - & 3,70 & 9,88 & 11,87 & 17,23 & 21,10 & $28,1 \pm 1$ & Humphrey et al. $(2003)^{\mathrm{a}, \mathrm{c}}$ \\
\hline
\end{tabular}


Tingkat sintasan tahap larva ikan pelangi arfak yang diperoleh dalam penelitian ini relatif rendah $(48,1 \%)$ sampai umur 41 hari, dan kondisi ini diduga terkait dengan pemilihan dan frekuensi pemberian makanan, terutama di antara umur 5 dan 14 hari. Pada periode ini, larva memasuki periode kritis, ketika kuning mulai habis. Makanan merupakan salah satu faktor yang memengaruhi pertumbuhan dan sintasan, terutama pada tahap perkembangan awal larva. Dalam periode ini, walaupun kondisi larva sudah aktif berenang, namun peluang bertemu dengan makanan yang sesuai dengan ukuran bukaan mulutnya masih relatif terbatas. Larva ikan mampu menelan makanan dengan ukuran yang sama dengan bukaan mulut, tetapi akan lebih memilih yang berukuran lebih kecil (Yúfera \& Darias 2007). Ukuran mangsa yang dipilih oleh larva ikan akan meningkat sesuai dengan ukuran bukaan mulut dan kemampuan mencari makan (Hunter 1984).

Tingkat sintasan dalam pemeliharaan larva sangat terkait tipe makanan, terutama terkait dengan ukuran. Perlakuaan penambahan kombinasi makanan akan menghasilkan tingkat sintasan larva yang lebih tinggi (Leu et al. 2010). Pemberian kombinasi makanan tambahan memberi banyak keuntungan bagi larva untuk mengubah ke makanan dengan ukuran yang berbeda, sesuai ukuran bukaan mulutnya. Dalam penelitian sebelumnya (Reid \& Holdway 1995, Humphrey et al. 2003), pemeliharaan larva ikan pelangi menggunakan kombinasi tipe makanan (dengan variasi ukuran) yang terdiri atas makanan alami dan komersial. Selain pengaruh tipe makanan, tingkat sintasan pada tahap larva juga dipengaruhi oleh suhu air. Tingkat sintasan yang rendah pada larva yang mulai mencari makan disebabkan oleh aktivitas mencari makan yang rendah, dan hal ini terutama terkait dengan kondisi suhu air (Olivotto et al. 2006). Pada kondisi pemeliharaan yang sesuai (tipe makanan dan suhu air), maka tingkat sintasan ikan pelangi $M$. splendida bisa mencapai $>90 \%$ sampai umur 3 bulan (Humphrey et al. 2003).

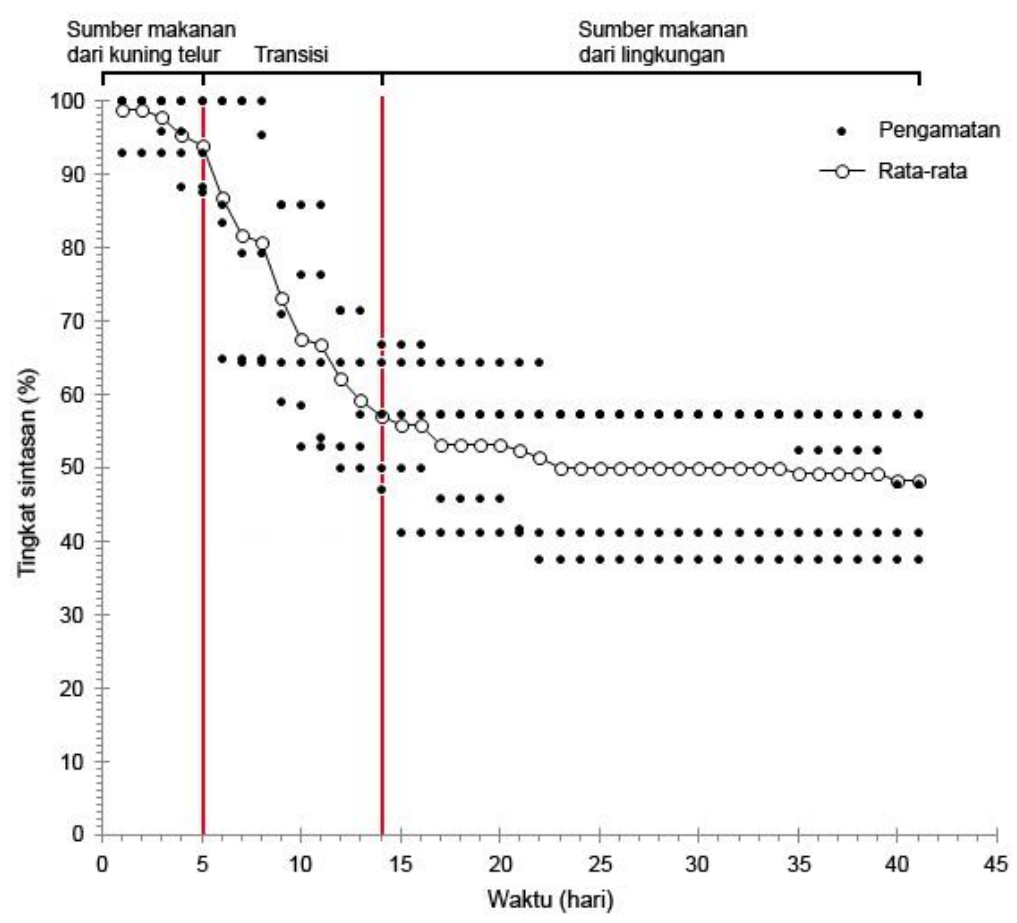

Gambar 6. Tingkat sintasan ikan pelangi arfak selama 41 hari pengamatan 


\section{Implikasi terhadap perkembangbiakan dalam penangkaran}

Penelitian ini memiliki implikasi dalam upaya perkembangbiakan dalam penangkaran dan pelepasliaran ikan pelangi arfak di habitat alami. Ikan pelangi arfak relatif memiliki karakteristik pemijahan dan pertumbuhan tahap awal yang relatif singkat yang akan sangat membantu keberhasilan dalam upaya penangkaran untuk perkembangbiakannya dalam periode yang singkat sehingga bisa mereduksi perubahan karakteristik alamiahnya. Selain itu, pertimbangan waktu yang tepat dalam pelepasliaran di habitat alami, untuk memaksimalkan sintasannya yaitu memerhatikan kestabilan habitat, suhu, dan ketersediaan makanan di alam.

Walaupun kecenderungan kondisi populasi ikan pelangi arfak belum diketahui (IUCN 2018), namun kualitas kondisi habitat alaminya yang semakin menurun (Manangkalangi et al. 2014, 2017, 2019, 2020, Leatemia et al. 2017, Lefaan et al. 2019), diduga akan berdampak terhadap penurunan populasi di habitat alaminya, khususnya di Sungai Nimbai dan Sungai Aimasi. Oleh karena itu perlu upaya konservasi spesies ikan ini, seperti kegiatan penangkaran (ex situ). Walaupun pada kenyataannya program penangkaran tidak sepenuhnya dapat memecahkan masalah konservasi, dan hanya diadopsi sebagai perlindungan terhadap kepunahan jenis sampai habitat alami kembali pulih dan fauna tersebut dapat dikembalikan kembali ke habitat aslinya (Philippart 1992; Snyder et al. 1996; Schönhuth et al. 2003).

\section{KESIMPULAN}

Karakteristik aktivitas pemijahan ikan pelangi Arfak berlangsung selama waktu pagi-siang hari dalam tiga periode yang menghasilkan sebanyak 78-116 telur. Telur menetas dalam periode 4-10 hari menjadi larva dengan panjang tubuh 4,13-4,40 mm. Pertumbuhan larva lambat sampai hari ke 8 dan meningkat sampai hari ke 23, dan kembali menurun. Tingkat sintasan sebesar $48,1 \%$ sampai pada pengamatan hari ke41.

\section{UCAPAN TERIMA KASIH}

Penulis menyampaikan terima kasih kepada F. N. Krey, H. V. Y. Monim, D. J. Sawaki, B. Duwit, D. Orisu, S. N. Yoku, P. Musyeri yang telah membantu pengumpulan contoh ikan pelangi arfak dari lapangan dan penanganannya dalam laboratorium. Juga disampaikan terima kasih kepada Ridwan Sala dan Indra F. Luhulima yang telah membaca manuskrip dan memberikan saran perbaikan, serta kepada Simon P. O. Leatemia selaku Kepala Laboratorium Perikanan FPIK UNIPA yang telah menyediakan sarana dan prasarana penunjang penelitian ini. Penulis juga menyampaikan ungkapan terima kasih kepada Kementerian Riset, Teknologi dan Pendidikan Tinggi atas dukungan Beasiswa Pendidikan Pascasarjana Dalam Negeri tahun 2014 dan Hibah Penelitian Doktor Tahun 2017 dengan no kontrak 089/SP2H/LT/ DRPM/IV/2017.

\section{DAFTAR PUSTAKA}

Allen GR. (1990). Les poisons arc-enciel (Melanotaeniidae) de la Péninsule de Vogelkop, Irian Jaya, avec description de trois Nouvelles espèces. Revue française d'Aquariologe. 16(4): 101-112

Balon EK. (1984). Patterns in the evolution of reproductive styles in fishes. In: Potts GW, Wootton RJ. (eds.). Fish reproduction: strategies and tactics. New York (USA): Academic Press. pp. 3552

Brown C. (2003). Habitat-predator association and avoidance in rainbowfish (Melanotaenia spp.). Ecology of Freshwater Fish. 12(2): $118-126$ 
Chivers DP, Smith RJF. (1994). Flathead minnows (Pimephales promelas) learn to recognize chemical stumuli from high-risk habitats by the presence of alarm substance. Behavioural Ecology. 6(2): $155-158$

Chivers DP, Smith RJF. (1995). Chemical recognition of risky habitats is culturally transmitted among flathead minnows, Pimephales promelas (Osteichthyes, Cyprinidae). Ethology. 99(4): 286-296

Crowley LELM, Ivantsoff W. (1982). Reproduction and early stages of development in two species of Australian rainbowfishes, Melanotaenia nigrans (Richardson) and Melanotaenia splendida inornata (Castelnau). Australian Zoologist. 21(1): 85-95

Crowley LELM, Ivantsoff W, Allen GR. (1986). Taxonomic position of two crimson-spotted rainbowfish, Melanotaenia duboulayi and Melanotaenia fluviatilis (Pisces: Melanotaeniidae), from eastern Australia, with special reference to their early life-history stages. Australian Journal of Marine and Freshwater Research. 37(3): 385398

Doupe RG, Schaffer J, Knott MJ, Burrows DW. (2009). How might an exotic fish disrupt spawning success in a sympatric native species? Marine and Freshwater Research. 60(5): 379-383

Einum S, Fleming IA. (1999). Maternal effects of egg size in brown trout (Salmo trutta): norms of reaction to environmental quality. Proceedings of the Royal Society B. 266(1433): 2095-2100

Einum S, Fleming IA. (2000). Highly fecund mothers sacrifice offspring survival to maximize fitness. Nature. 405: 565-567

Einum S, Fleming IA. (2004) Environmental unpredictability and offspring size: Conservative versus diversified bet-hedging. Evolutionary Ecology Research. 6: 443-455

Flint N, Pearson RG, Crossland MR. (2018). Reproduction and embryo viability of a range-limited tropical freshwater fish exposed to fluctuating hypoxia. Marine and Freshwater Research. 69(2): 267-276

Greig SM, Sear DA, Carling PA. (2005a). The impact of fine sediment accumulation on the survival of incubating salmon progeny: implications for sediment management. Science of The Total Environment. 344(1-3): 241-258

Greig SM, Sear DA, Smallman D, Carling PA. (2005b). Impact of clay particles on cutaneous exchange of oxygen across the chorion of Atlantic salmon eggs. Journal of Fish Biology. 66(6): 1681-1691

Greig SM, Sear DA, Carling PA. (2007). A field-based assessment of oxygen supply to incubating Atlantic salmon (Salmo salar) embryos. Hydrological Processes. 21(22): 3087-3100

Hattori A, Warburton K. (2003). Microhabitat use by the rainbowfish Melanotaenia duboulayi in a subtropical Australian stream. Journal of Ethology. 21(1): 15-22

Hismayasari IB, Rahayu S, Marhendra APW. (2015). Ovary maturation stages histology and follicles diameter of Melanotaenia boesemani rainbowfish ovary 
from district of North Ayamaru, Maybrat Regency, West Papua. Journal of Morphological Science. 32(3): 157-164

Houde ED. (1994). Differences between marine and freshwater fish larvae: implications for recruitment. ICES Journal of Marine Science. 51(1): 91-97

Humphrey C, Klumpp DW, Pearson R. (2003). Early development and growth of the eastern rainbowfish, Melanotaenia splendida splendi$d a$ (Peters) I. Morphogenesis and ontogeny. Marine and Freshwater Research. 54(1): 17-25

Humphries P, King AJ, Koehn JD. (1999). Fish, flows and flood plains: links between freshwater fishes and their environment in the Murray-Darling River Systems, Australia. Environmental Biology of Fishes. 56(1-2): 129-151

Hunter JR. (1984). Feeding ecology and predation of marine fish larvae. In: R. Lasker (ed.). Marine fish larvae: morphology, ecology and relation to fisheries. Seattle, WA (USA): Washington Sea Grant Program. pp. 34-77

Hutchings JA. (1997). Life history responses to environmental variability in early life. In: Chambers RC, Trippel EA. (eds.). Early life history and recruitment in fish populations. Fish and Fisheries Series 21. London (UK): Chapman and Hall. pp. 139-168

IUCN. (2018). The IUCN red list of threatened species. Version 20173. [accessed: 7 May 2018]. http://www.iucnredlist.org

Kadarusman, Sudarto, Paradis E, Pouyaud L. (2010). Description of Melanotaenia fasinensis, a new species of rainbowfish (Melanotaeniidae) from West Papua, Indonesia with comments on the rediscovery of $M$. ajamaruensis and the endagered status of M. parva. Cybium. 34(2): $207-215$

Kendall AW Jr, Ahlstrom EH, Moser HG. (1984). Early life history stages of fishes and their characters. In: Moser HG, Richards WJ, Cohen DM, Fahay MP, Kendall AW Jr, Richardson SL (eds.). Ontogeny and systematics of fishes. California (USA): American Society of Ichthyologists and Herpetologists. pp 11-22

Kjesbu OS, Witthames PR, Solemdal P, Walker MG. (1998). Temporal variations in the fecundity of Arcto-Norwegian cod (Gadus morhua) in response to natural changes in food and temperature. Journal of Sea Research. 40(3-4): 303-321

Leatemia SPO, Manangkalangi E, Lefaan PT, Peday HFZ, Sembel L. (2017). Makroavertebrata bentos sebagai bioindikator kualitas air Sungai Nimbai Manokwari, Papua Barat. Jurnal Ilmu Pertanian Indonesia. 22(1): 25-33

Lefaan PT, Peday HFZ, Leatemia SPO, Sembel L, Manangkalangi E. (2019). Struktur vegetasi riparia dan implikasinya terhadap kondisi habitat ikan pelangi arfak, Melanotaenia arfakensis di Sungai Nimbai, Manokwari Papua Barat. Samakia: Jurnal Ilmu Perikanan. 10(1): 38-56

Leu M-Y, Meng P-J, Huang C-S, Tew KS, Kuo J, Liou C-H. (2010). Spawning behavior, early development and first feeding of the bluestriped angelfish 
[Chaetodontoplus septentrionalis (Temminck \& Schlegel, 1844)] in captivity. Aquaculture Research. 41: e39-e52

Lobon-Cervia J, Utrilla CG, Rincøn PA, Amezcua F. (1997). Environmentally induced spatiotemporal variations in the fecundity of brown trout Salmo trutta L.: Trade-offs between egg size and number. Freshwater Biology. 38(2): 277-288

Maddern MG, Morgan DL, Gill HS. (2007). Distribution, diet and potential ecological impacts of the introduced Mozambique mouthbrooder Oreochromis mossambicus Peters (Pisces: Cichlidae) in Western Australia. Journal of the Royal Society of Western Australia. 90(4): 203-214

Manangkalangi E. (2009). Makanan, pertumbuhan dan reproduksi ikan pelangi arfak (Melanotaenia arfakensis Allen) di Sungai Nimbai dan Sungai Aimasi, Manokwari. [Tesis]. Bogor (ID): Institut Pertanian Bogor. 105 hal

Manangkalangi E, Rahardjo MF, Sjafii DS. (2009a). Habitat ontogeni ikan pelangi arfak (Melanotaenia arfakensis) di Sungai Nimbai dan Sungai Aimasi, Manokwari. Jurnal Natural. 8(1): 4-11

Manangkalangi E, Rahardjo MF, Sjafii DS, Sulistiono. 2009b. Musim pemijahan ikan pelangi arfak (Melanotaenia arfakensis Allen) di Sungai Nimbai dan Sungai Aimasi, Manokwari. Jurnal Iktiologi Indonesia. 9(1): 1-12

Manangkalangi E, Rahardjo MF, Sjafii DS, Sulistiono. (2009c). Pengaruh Kondisi Hidrologi Terhadap Komunitas Makroavertebrata di Sungai Aimasi dan Sungai Nimbai, Manokwari. Jurnal
Perikanan dan Kelautan. 5(2): 99110

Manangkalangi E, Leatemia SPO, Lefaan PT, Peday HFZ, Sembel L. (2014). Kondisi habitat ikan pelangi arfak, Melanotaenia arfakensis, 1990 di Sungai Nimbai, Prafi Manokwari. Jurnal Iktiologi Indonesia. 14(1): 21-36

Manangkalangi E, Rahardjo MF, Hadiaty RK, Hariyadi S. (2017). Efektivitas ikan pelangi arfak, Melanotaenia arfakensis Allen, 1990 dalam mencari makan pada tingkat kekeruhan air yang berbeda: suatu pendekatan laboratorium. Jurnal Iktiologi Indonesia. 17(3): 299-310

\section{Manangkalangi E, Rahardjo MF, Hadiaty RK, Hariyadi S, Simanjuntak CPH. (2019). Trophic ecology of fish community at Nimbai Stream: competition and predation interaction to Arfak rainbowfish, Melanotaenia arfakensis Allen, 1990. Jurnal Iktiologi Indonesia. 19(3): 449-464}

Manangkalangi E, Rahardjo MF, Hadiaty RK, Hariyadi S, Simanjuntak CPH. (2020). Distribution and abundance of the Arfak rainbowfish, Melanotaenia arfakensis Allen, 1990 in Prafi River system, Manokwari, West Papua: due to habitat degradation? IOP Conference Series: Earth and Environmental Science. 404: 012043

Miller TJ, Crowder LB, Rice JA, Marschall EA. (1988). Larval size and recruitment mechanisms in fishes: toward a conceptual framework. Canadian Journal of Fisheries and Aquatic Sciences. 45(9): 1657-1670

Milton DA, Arthington AH. (1984). Reproductive strategy and growth 
of the crimson-spotted rainbowfish, Melanotaenia splendida fluviatilis (Castelnau) (Pisces: Melanotaeniidae) in south-eastern Queensland. Australian Journal of Marine and Freshwater Research. 35(1): 7583

Morgan DL, Gill HS, Maddern MG, Beatty SJ. (2004). Distribution and impacts of introduced freshwater fishes in Western Australia. New Zealand Journal of Marine and Freshwater Research. 38(3): 511-523

Olden JD, Kennard MJ. (2010). Intercontinental comparison of fish life history strategies along a gradient of hydrologic variability. In: Gido KB, Jackson DA (eds.). Community ecology of stream fishes: concepts, approaches, and techniques. Proceedings of a symposium held in Ottawa, Ontario, Canada, 19-20 August 2008. Bethesda (USA): American Fisheries Society. pp. 83-107

Oliveira RF, Almada VC. (1998). Maternal aggression during the mouthbrooding cycle in the cichlid fish, Oreochromis mossambicus. Aggressive Behavior. 24: 187-196

Oliveira RF, Almada VC, Canário AVM. (1996). Social modulation of sex steroid concentrations in the urine of male cichlid fish Oreochromis mossambicus. Hormones and Behavior. 30(1): 2-12

Olivotto I, Holt SA, Carnevali O, Holt GJ. (2006). Spawning, early development, and first feeding in the lemonpeel angelfish Centropyge flavissimus. Aquaculture. 253(1-4): 270-278
Oulton LJ, Haviland V, Brown C. (2013a). Predator recognition in rainbowfish, Melanotaenia duboulayi, embryos. PLoS ONE. 8(10): e76061

Oulton LJ, Carbia P, Brown C. (2013b). Hatching success of rainbowfish eggs following exposure to air. Australian Journal of Zoology. 61(5): 395-398

Philippart JC. (1992). Is captive breeding an effective solution for the conservation of endemic species? Biological Conservation. 72(2): 281-295

Portella MC, Dabrowski K. (2008). Diets, physiology, biochemistry and digestive tract development of freshwater fish larvae. In: Cyrino JEP, Bureau DP, Kapoor BG (eds.). Feeding and digestive functions in fishes. Enfield, $\mathrm{NH}$ (USA): Science Publishers. pp. 227-279

Pusey BJ, Arthington AH, Bird Jr JR, Close PG. (2001). Reproduction in three species of rainbowfish (Melanotaeniidae) from rainforest streams in northern Queensland, Australia. Ecology of Freshwater Fish. 10(2): 75-87

Pusey BJ, Arthington AH, Close PG, Bird JR. (2002). Larval fishes in rainforest streams: recruitment and microhabitat use. Proceedings of the Royal of Queensland. 110: 27-46

Radael MC, Cardoso LD, Andrade DR, Mattos D, Motta JH, Manhães JV, Vidal Jr MV. (2013). Morphophysiological

characterization of the embryonic development of Melanotaenia praecox (Weber \& de Beaufort, 1922). Zygote. 22(4): 533-539 
Radael MC, Cardoso LD, de Andrade DR, Ferreira AV, de Cruz Mattos D, Vidal Jr MV. (2015). Effect of temperature on embryonic development of Melanotaenia boesemani (Allen and Cross, 1982). Zygote. 24(2): 301-309

Reid HP, Holdway DA. (1995). Early development of the Australian crimson-spotted rainbowfish, Melanotaenia fluviatilis (Pisces: Melanotaeniidae). Marine and Freshwater Research. 46(2): 475480

Rice JA, Crowder LB, Holey ME. (1987). Exploration of mechanisms regulating larval survival in Lake Michigan bloater: a recruitment analysis based on characteristics of individual larvae. Transactions of the American Fisheries Society. 116(5): 703-718

Rønnestad I, Morais S. (2008). Digestion. In: Finn RN, Kapoor BG (eds.). Fish larval physiology. Enfield, NH (USA): Science Publishers. pp. 201-262.

Schönhuth S, Luikart G, Doadrio I. (2003). Effects of a founder event and supplementary introductions on genetic variation in a captive breeding population of the endangered Spanish killifish. Journal of Fish Biology. 63(6): 1538-1551

Siby LS, Rahardjo MF, Sjafei DS. 2009. Biologi reproduksi ikan pelangi merah (Glossolepis incisus, Weber 1907) di Danau Sentani. Jurnal Iktiologi Indonesia. 9(1): 49-61

Simanjuntak, C.P.H., Kinoshita I, Fujita S, Takeuchi K. (2015). Reproduction of the endemic engraulid, Coilia nasus, in freshwaters inside a reclamation dike of Ariake Bay, western Japan. Ichthyological Research. 62 (3): 374-378

Singh RK, Khandagale PA, Chavan SL, Sapkale PH. (2006). The relationship of ova diameter to fertilization rates, hatching rates, survival percentages and specific growth rates in the common carp and indian major carps. Asian Fisheries Society. 19(3): 257-269

Snyder NFR, Derrickson SR, Beissinger SR, Wiley JW, Smith TB, Toone WD, Miller B. (1996). Limitations of captive breeding in endangered species recovery. Conservation Biology. 10(2): 338348

Winemiller KO, Rose KA. (1992). Patterns of life-history diversification in North American fishes: implications for population regulation. Canadian Journal of Fisheries and Aquatic Sciences. 49(10): 2196-2218.

Wootton RJ. (1984). Introduction: tactics and strategies in fish reproduction. In: Potts GW, Wootton RJ (eds.). Fish reproduction: strategies and tactics. New York (USA): Academic Press. pp. 1-12.

Wootton RJ. (1990). Ecology of Teleost Fishes. New York (USA): Chapman and Hall Ltd. $404 \mathrm{p}$

Yúfera M, Darias MJ. (2007). The onset of exogenous feeding in marine fish larvae. Aquaculture. 268(14): 53-63.

Yuliani F, Musthofa SZ, Kadarini T, Elfidasari D. (2013). Perkembangan larva ikan rainbow boesemani (Melanotaenia boesemani): tahap pembentukan sirip dan pembelokan tulang ekor. Unnes Journal of Life Science. 2(2): 100-104. 
Zambonino-Infante JL, Gisbert E, Sarasquete C, Navarro I, Gutiérrez J, Cahu CL. (2008). Ontogeny and physiology of the digestive system of marine fish larvae. In: Cyrino JEP, Bureau DP, Kapoor BG (eds.). Feeding and digestive functions in fishes. Enfield, NH (US). 
